\title{
Analysis of College English Teaching Reform Based on Dialogism Theory
}

\author{
Meijing LI \\ Foreign Language Department \\ Jilin Business and Technology College \\ Changchun City, China, \\ Email:lihongbin1975@163.com
}

\begin{abstract}
College English teaching has made a great progress in recent years. However, the urgent needs of the society for high-level English-majored innovative talents make college English teaching face severe challenges. What's more, textbooks compiling and curriculum teaching suffer from bottlenecks, it is a necessity to innovate the current teaching mode. This paper attempts to introduce Bakhtin's dialogism theory into teaching activities through multi-dimensional interpretation and analysis in order to seek the relevance of the theory to actual teaching in colleges, and puts forward teaching concept, curriculum mode and textbook compiling plan accordingly, thus, it is possible to explore and establish a dialogue-based teaching mode, which makes college Englishmajored talents form an insight to grasp the essence of foreign culture, innovation capability and an artistic way of thinking instead of being confined to the solid language knowledge and skills.
\end{abstract}

Keywords-College English majors; Dialogism theory; Research teaching

Bakhtin is a famous literary theorist and literary symbologist in the 20th century. Through the interpretation of Bakhtin's dialogism theory, the author finds that the theory has an obvious practical relevance to research teaching of college English majors. The application of Bakhtin's dialogism theory in the field of English teaching not only provides a new perspective of thinking for the relevant theoretical research, but also helps to regenerate new vitality in college research teaching practice.

\section{THE INTERPRETATION OF BAKHTIN'S DIALOGISM THEORY}

From the perspectives of dialogical relationship and dialogical thought, this paper firstly carries on an in-depth analysis of Bakhtin's dialogism theory to build a theoretical basis for the college teaching research of English majors.

\section{A. Dialogical relationship}

Bakhtin pointed out that polyphonic novel has two basic modes of dialogue: the dialogue between characters and the characters' inner dialogue. In this sense, there is a similarity in the author-hero relationships according to Bakhtin's dialogism theory and teacher-student relationship in research-oriented teaching. College English teachers, who play a leading role of in English teaching, are supposed to make their students actively think and fully express their language skills in the teaching process.

\section{B. Dialogical thought}

Bakhtin expounded and analyzed dialogue from the perspective of literary theory and criticism and developed dialogue to be a humanistic way of thinking. He argued that thought is essentially a dialogue, and dialogical thinking reflects the law of thinking, which is also advocated by college English-majored teaching. Language and culture is the main content of English teaching, which cannot be fully interpreted through scientific thinking paradigm. It is possible to fundamentally internalize professional discipline knowledge and improve thinking ability to set up the artistic thinking of pluralism and coexistence and observe cultural phenomenon with a broad vision. ${ }^{[1]}$

\section{ENLIGHTENMENT OF DIALOGISM THEORY ON COLLEGE ENGLISH-MAJORED TEACHING}

Through the above interpretation, we find that there is a similarity in the author-hero relationships according to Bakhtin's dialogism theory and teacher-student relationship in research-oriented teaching. The former has a profound significance to the latter. Only when there is an equal dialogical relationship established between teaching and learning can teachers make the teaching turn monologue into dialogue and fundamentally establish a teaching mode integrating research and teaching.

\section{A. From monologue to dialogue.}

Under the influence of traditional view of language, teaching concept and thinking paradigm, teachers play a unique role in English teaching activities, and classroom discourse is a monologue, which is essentially a copy or reproduction of knowledge. The teaching concept of "monologue" is difficult to adapt to the needs of modern society, so, there must be a transformation from monologue to dialogue. 


\section{1) A dialogical relationship between teachers and students}

The relationship between teachers and students is usually generated in the process of education for a common education task and a mutual interaction. Teachers can establish a teacher-student dialogical relationship in the research-oriented college English teaching and deconstruct their authority of discourse so as to establish a studentcentered and teacher-led teaching atmosphere. In such a relationship between teachers and students, students become the main body of dialogue and actively involve into English acquisition. Teachers, on the other hand, turn into interlocutors, who aim to cultivate the students' interest in learning English through teaching design, inspiration and guidance in students' learning process. ${ }^{[2]}$

\section{2) Open-ended class discourse}

In English teaching, classroom discourse is not only the medium of teaching, but also an important source of target language input. An open classroom discourse is the key link from monologue to dialogue in the process of teaching. In the classroom teaching, to create more opportunities for dialogue between students and teachers can strengthen the interaction between language and thinking.

\section{3) Interactive teaching mode}

Interactive teaching can establish a platform for interaction between students and teachers. Firstly, it aims to encourage and inspire students' autonomous learning. Teachers must focus on students, inspire and activate students' understanding of background knowledge, and promote the students to internalize the real teaching content. Teachers can encourage students to think independently and cultivate the correct learning strategies through the class debate, group discussion and other forms of teaching. Teachers should notice fine processing of input information and interact with students through implicit discourse. When students have problems, teachers should pay attention to guidance of thinking methods, and help students broaden the thinking. In addition, teachers should master the ability to control the interactive scene and give students tips, inspiration and guidance on the key points. Secondly, the problem-based teaching guides students to solve the complex and practical problems, make students construct a broad and flexible knowledge basis and cultivate their skills and motivation for lifelong learning.

\section{B. Reform and improve curriculum}

1) The reconstruction of curriculum structure and addition of new majors

College English major is a special subject, because students should not only learn a foreign language, but also learn professional knowledge. First of all, culture should be paid great attention to, which requires college set up courses widely taking human civilization as the main content of courses, including comparative literature and comparative culture. Language teaching should make students get the cognitive development and improve the sensibility of foreign culture and insight in the process of actively participating in the target language culture. Secondly, it is necessary to set courses to advocate western thought and strengthen students' critical awareness. Western thought course is an important way to understand western culture, which should give priority to discussion. The classic western reading comprehension extends the students' humanities knowledge and trains their thinking ability and critical spirit.

\section{2) Hierarchical teaching model combined with} curriculum elective system

Hierarchical teaching mode follows the humanistic education concept of "vary from person to person, according to their aptitude". According to the individual needs and different levels of English, students can be divided into different levels in actual teaching. It has clear standards for English and a higher level of English application ability, so, this course has much practicability, selectivity and openness. Hierarchical teaching is combined with elective system, whose advantage lies in its adaptation to the diversity of students and promotion of the development of students' variety of potential personality and skills. At the same time, it can expand students' knowledge, broaden students' horizons, and cultivate students' cultural quality and innovation spirit. This combination is conducive to implementing small-class teaching, making the teachers and learners have more direct communication opportunities and building naturally relaxed learning environment.

\section{3) Diversified and innovative teaching methods}

Diversified and innovative teaching methods advocate to adopt diversified teaching forms and to combine students' autonomous learning with teachers' academic lectures and class discussions. In terms of literature, college English class should adapt to the pace of the English literary studies abroad. ${ }^{[3]}$ In terms of translation course, it needs pay equal attention to theory and practice, and translation and interpretation. Teachers should realize the importance of the dialogue between teachers and students and guide students to complete some of the problems. Teachers should also encourage students to have innovative consciousness and pioneering spirit, learn to analyze and judge without constrained by rules and restrictions, and constantly improve the learning ability, practical ability and research ability.

\section{Dialogic TEACHING AND TeXtBook CompIling}

To really change the traditional teaching mode and establish research-oriented dialogic teaching mode, strengthening the construction of English major teaching material is an essential part of the college English teaching reform. According to the Bakhtin's dialogue theory and its enlightenment, college English teaching reform must give attention to the cultivation of outstanding comprehensive quality and thinking ability.

\section{A. Textbook compiling}

Teaching material with a certain depth and breadth of knowledge is able to cultivate students" "question consciousness" and inspire students to think over social and historic problems. These problems give students sufficient 
space and opportunity to explore and develop the students' imagination and creativity. Such teaching materials are no longer static mediums to present language points, but underline the practice of thinking ability, which lays a good foundation for the combination of teaching and research. Through a unique text and teaching design, students can be encouraged to participate in classroom activities and flexibly use language in different language forms.

\section{B. Teaching material content-paying equal attention to humanities and science}

English teaching material should strive to become the leading course of humanities education in language learning. In addition to the separated courses in cultivating thoughts and culture, it can also be integrated into the introduction of western civilization and the related interaction in other courses. In the process of learning activities, students can have a good knowledge of British and American culture and social and historic knowledge. Through discussing and analyzing of the deep cultural connotation, understanding of different civilizations and mastering the basic knowledge of humanities, it can cultivate students' comprehensive cultural quality and improve their ability of intercultural communication. Through the comparison of different civilizations and culture connotations, students not only obtain the cognitive development but also form more sensibility to the essence of foreign culture and insight. At the same time, the English major teaching materials should reflect the latest research results on the various subjects and areas, such as student interest in natural science knowledge and way of thinking, which shows the integration of subjects and the contemporaneity of knowledge.

\section{Teaching material forms -co-construction of teachers and students}

Teaching material serves teachers and students in teaching activities, including textbooks, teaching reference books and electronic materials. New English teaching materials can't stay on the traditional concept of paper textbooks, but should include all kinds of teaching resources. Knowledge provided by three-dimensional textbooks has the intuitive, interactive and easy-control characteristics, which can provide students with multiple stimuli and attract them to participate in the experience and exploration of teaching activities.

Dialogism theory embodies a kind of social concept with equality and openness. It acknowledges differences and advocates seeking common ground while putting aside differences. It denies the existence of definite answer and advocates uncertainty of open thinking. In this sense, Bakhtin's dialogism theory is unable to complete dialogue. Rreaders of different times will continue to dialogue with Bakhtin and make interpretation of dialogism theory. In short, the implementation of the dialogism theory in college English teaching will be a long-term systematic project, and this paper hopes that the research conducted can lead to more English teaching workers thinking from different perspectives and excavating the unique charm of English teaching.

\section{REFERENCE}

[1] Bakhtin. Collected works of Bakhtin[M]. Shijiazhuang: Hebei Education Press, 1998

[2] College English syllabus revision group. College English Teaching Syllabus.[M]. Shanghai:Shanghai Foreign Language Education Press, 1999

[3] Benson. P. Teaching and Researching Autonomy in Language Learning [M]. Beijing: Foreign Language Teaching and Research Press, 2005 